\title{
Exceptional Adsorption and Binding of Sulfur Dioxide in a Robust Zirconium-Based Metal-Organic Framework
}

Joseph H. Carter, ${ }^{\dagger \neq}$ Xue Han, ${ }^{\dagger}$ Florian Y. Moreau, ${ }^{\dagger}$ Ivan da Silva, ${ }^{\S}$ Adam Nevin, ${ }^{\dagger}$ Harry G. W. Godfrey, ${ }^{\dagger}$ Chiu C. Tang, Sihai Yang, $* \dagger \odot$ and Martin Schröder* ${ }^{*} \oplus \bullet$

${ }^{\dagger}$ School of Chemistry, University of Manchester, Manchester M13 9PL, United Kingdom

${ }^{\ddagger}$ Diamond Light Source, Harwell Science Campus, Oxfordshire OX11 0DE, United Kingdom

${ }^{\S}$ ISIS Facility, STFC Rutherford Appleton Laboratory, Oxfordshire OX11 0QX, United Kingdom

Supporting Information

ABSTRACT: We report a record-high $\mathrm{SO}_{2}$ adsorption capacity of $12.3 \mathrm{mmol} \mathrm{g}^{-1}$ in a robust porous material, MFM-601, at $298 \mathrm{~K}$ and 1.0 bar. $\mathrm{SO}_{2}$ adsorption in MFM601 is fully reversible and highly selective over $\mathrm{CO}_{2}$ and $\mathrm{N}_{2}$. The binding domains for adsorbed $\mathrm{SO}_{2}$ and $\mathrm{CO}_{2}$ molecules in MFM-601 have been determined by in situ synchrotron X-ray diffraction experiments, giving insights at the molecular level to the basis of the observed high selectivity.

$\mathrm{T}$ he International Energy Outlook 2017 report produced by the U.S. Energy Information Administration predicts that fossil fuels will account for $\sim 77 \%$ of global energy production in 2050, with coal comprising a major component of the overall energy supply. ${ }^{1}$ The burning of bituminous, subbituminous and lignite coals produces $\mathrm{SO}_{2}$ at a concentration of between 500 and 3000 ppm, around 95\% of which is removed via limestone-scrubbing or the wet-sulfuric-acid processes. ${ }^{2}$ Although these processes are effective, as much as $400 \mathrm{ppm}$ of $\mathrm{SO}_{2}$ can remain in the exhaust gas, which, when vented to the atmosphere, poses significant health risks and environmental impact. ${ }^{3}$ Small amounts of $\mathrm{SO}_{2}$ in flue gas can also react with organo-amines used for $\mathrm{CO}_{2}$-scrubbing causing permanent loss of activity. ${ }^{4}$ Physisorption of $\mathrm{SO}_{2}$ by porous materials such as zeolites, ${ }^{5}$ mesoporous silica, ${ }^{6}$ ionic microgels ${ }^{7}$ and activated carbons ${ }^{8}$ using supramolecular host-guest interactions is a promising approach that can give high selectivity, reversibility and low energy penalty for system regeneration. However, these materials generally suffer from low adsorption capacities and exposure to $\mathrm{SO}_{2}$ often leads to irreversible structural degradation.

Metal-organic frameworks (MOFs) are emerging porous materials constructed from metal clusters with organic linkers, ${ }^{9}$ and their tuneability makes them interesting candidates for many applications. ${ }^{10}$ Although much work has focused on the study of gas separations in MOFs, very little effort has been devoted to the sequestration of $\mathrm{SO}_{2},{ }^{11}$ since it often leads to severe structural degradation of the material and/or irreversible uptake. Here, we report the exceptional adsorption and reversible binding of $\mathrm{SO}_{2}$ in two Zr-based MOFs, MFM-600 and MFM-601. MFM-601 is obtained by postsynthetic removal of a linker in an ordered, predictable pattern from
MFM-600. This is accompanied by significant enhancement of gas adsorption in MFM-601, notably simultaneous increases in $\mathrm{SO}_{2}$ uptake (146\%) and selectivity over $\mathrm{CO}_{2}$ and $\mathrm{N}_{2}$. Significantly, MFM-601 shows a $\mathrm{SO}_{2}$ adsorption capacity of $12.3 \mathrm{mmol} \mathrm{g}^{-1}$ at $298 \mathrm{~K}$ and $1.0 \mathrm{bar}$, representing the highest value observed to date in porous materials under the same conditions. In addition, the binding domains for adsorbed $\mathrm{CO}_{2}$ and $\mathrm{SO}_{2}$ in MFM-610 have been determined by in situ synchrotron X-ray diffraction.

$4,4^{\prime}, 4^{\prime \prime}, 4^{\prime \prime \prime}$-(1,4-Phenylenebis(pyridine-4,2,6-triyl))tetra benzoic acid $\left(\mathrm{H}_{4} \mathrm{~L}\right.$, Scheme 1$)$ was prepared via a three-step

Scheme 1. Synthesis of MFM-601 from 4,4', $4^{\prime \prime}, 4^{\prime \prime \prime}-(1,4-$ Phenylenebis(pyridine-4,2,6-triyl))tetrabenzoic Acid $\left(\mathrm{H}_{4} \mathrm{~L}\right)$

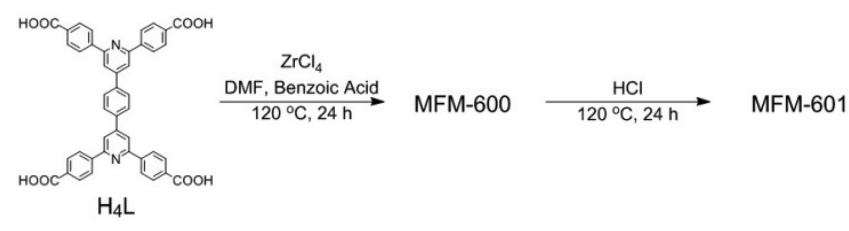

synthesis (Scheme S1). $\left[\mathrm{Zn}_{6}\left(\mu_{3}-\mathrm{O}\right)_{4}\left(\mu_{3}-\mathrm{OH}\right)_{4}(\mathrm{OH})_{4}(\mathrm{~L})_{2}-\right.$ $\left.\left(\mathrm{H}_{4} \mathrm{~L}\right)_{0.7}\right]$ (MFM-600) was synthesized by heating a mixture of $\mathrm{ZrCl}_{4}, \mathrm{H}_{4} \mathrm{~L}$ and benzoic acid as modulator in DMF at 120 ${ }^{\circ} \mathrm{C}$ for $24 \mathrm{~h}$ and was isolated as plate-shaped colorless single crystals. The single crystal X-ray structure shows that MFM600 contains $\left[\mathrm{Zr}_{6}\left(\mu_{3}-\mathrm{O}\right)_{4}\left(\mu_{3}-\mathrm{OH}\right)_{4}(\mathrm{OH})_{4}\right]^{8+}$ clusters, first observed in UiO-66. ${ }^{12}$ In this cluster the six $\mathrm{Zr}^{\mathrm{IV}}$ ions form an octahedron with the 8 faces each capped by a $\mu_{3}-\mathrm{O}$ or $\mu_{3}$ $\mathrm{OH}$. Eight of the edges of the octahedron are bridged by $\mathrm{L}^{4-}$ linkers via bidentate carboxylate groups with the remaining four equatorial edges each bridged by a $\mathrm{H}_{4} \mathrm{~L}$ linker (occ = 0.35 ) that is monodentate to each equatorial $\mathrm{Zr}(\mathrm{IV})$ center and bound through the $\mathrm{C}=\mathrm{O}$ moiety of the carboxylate groups (Figure S4). The coordination sphere at the equatorial $\mathrm{Zr}(\mathrm{IV})$ centers is completed by a terminal $\mathrm{OH}^{-}$ligand.

MFM-600 was treated with an $8 \mathrm{M}$ solution of $\mathrm{HCl}$, which led to a structural phase transition to MFM-601, $\left[\mathrm{Zn}_{6}\left(\mu_{3}-\right.\right.$ $\left.\mathrm{O})_{4}\left(\mu_{3}-\mathrm{OH}\right)_{4}(\mathrm{OH})_{4}\left(\mathrm{H}_{2} \mathrm{O}\right)_{4}(\mathrm{~L})_{2}\right]$, the structure of which was determined by high resolution synchrotron powder X-ray diffraction with the $\left\{\mathrm{Zr}_{6}\right\}$ node assigned to the MIX-staggered

Received: August 7, 2018

Published: November 12, 2018 
proton topology. ${ }^{13}$ In MFM-601, the $\mathrm{H}_{4} \mathrm{~L}$ monodentate linkers from the equatorial positions of the $\left\{\mathrm{Zr}_{6}\right\}$ cluster have been removed (Figure 1) and replaced with terminal $\mathrm{H}_{2} \mathrm{O}$

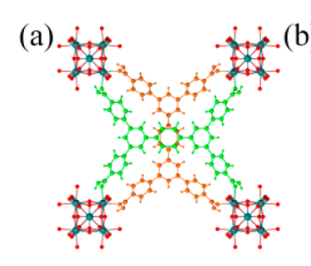

(d)
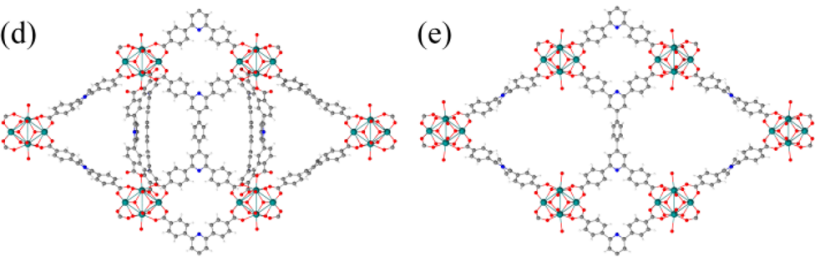

Figure 1. Views of (a) disordered $\mathrm{H}_{4} \mathrm{~L}$ linker present in MFM-600; (b) "fully bound" L"- linker present in MFM-600 and MFM-601; (c) $\left\{\mathrm{Zr}_{6}\right\}$ node present in MFM-600 and MFM-601; (d) structure of MFM-600; (e) structure of MFM-601.

molecules. As a result, the alternating linkage between the $\left[\mathrm{Zr}_{6}\left(\mu_{3}-\mathrm{O}\right)_{4}\left(\mu_{3}-\mathrm{OH}\right)_{4}(\mathrm{OH})_{4}\left(\mathrm{H}_{2} \mathrm{O}\right)_{4}\right]^{8+}$ cluster and the $\mathrm{L}^{4-}$ linker yields two types of channels of $\sim 9 \AA$ (cylinder-shaped) and $\sim 12 \AA$ (waterdrop-shaped) diameter running through the structure of MFM-601 along the $c$-axis. This leads to an increase in the BET surface area from $2281 \mathrm{~m}^{2} \mathrm{~g}^{-1}$ for MFM600 to $3644 \mathrm{~m}^{2} \mathrm{~g}^{-1}$ for MFM- 601 , a rise of $\sim 60 \%$. We note that MFM-601 has recently been reported (as BUT-15) as an adsorbent for $\mathrm{Fe}^{\mathrm{III}}$ ions in water. ${ }^{14}$ Acid treatment has been previously reported as an efficient approach to remove free ligands such as surplus benzoic acid modulator in Zr-based MOFs ${ }^{15}$ and as a method of improving the $\mathrm{N}_{2}$ uptake in $\mathrm{UiO}$ $66^{16}$

Sorption isotherms of $\mathrm{SO}_{2}, \mathrm{CO}_{2}$ and $\mathrm{N}_{2}$ were measured on desolvated samples. As expected, the higher BET surface area of MFM-601 allows a greater total uptake of all three gases. MFM-600 displays a two-step Type-IV isotherm for $\mathrm{SO}_{2}$ with an excess uptake of $5.0 \mathrm{mmol} \mathrm{g}^{-1}$ at $298 \mathrm{~K}$ and 1.0 bar. Interestingly, in comparison, MFM-601 exhibits a type-I isotherm for $\mathrm{SO}_{2}$ leading to an exceptionally high uptake of $12.3 \mathrm{mmol} \mathrm{g}^{-1}$ (146\% enhancement) at $298 \mathrm{~K}$ and $1.0 \mathrm{bar}$, representing the highest value observed in porous solids and notably higher than a range of best-behaving $\mathrm{SO}_{2}$ sorbents (Table S1). Importantly, no loss of adsorption capacity of $\mathrm{SO}_{2}$ was observed in MFM-601 over five cycles of adsorption/ desorption (Figure S17b). The $\mathrm{SO}_{2}$ uptake in MFM-601 is further increased to $16.9 \mathrm{mmol} \mathrm{g}^{-1}$ at $273 \mathrm{~K}$ and $1.0 \mathrm{bar}$ (Figure S17a). MFM-601 shows fully reversible adsorption of $\mathrm{SO}_{2}$ at both 273 and $298 \mathrm{~K}$, allowing the total evacuation of the framework upon desorption under pressure-swing conditions (Figure 2) with no structural phase change or framework collapse, as evidenced by the postsorption PXRD patterns (Figure S8). This is in contrast to the current leading $\mathrm{SO}_{2}$ sorbent, MFM-202a, which undergoes irreversible phase change to MFM-202b upon $\mathrm{SO}_{2}$ adsorption, ${ }^{17}$ and $\mathrm{Ni}(\mathrm{bdc})$ (ted) 0.5 and MOF-74(Mg), which release up to $40 \%$ of the captured $\mathrm{SO}_{2}$ upon desorption. ${ }^{18}$ The desorption of $\mathrm{SO}_{2}$ from SIFSIX-1-Cu has not been reported. ${ }^{20 a}$ Interestingly, the high uptake of $\mathrm{SO}_{2}$ in MFM-601 does not correlate with equivalent increases in uptake of $\mathrm{CO}_{2}$ or $\mathrm{N}_{2}$. The uptake of $\mathrm{CO}_{2}$ in MFM-
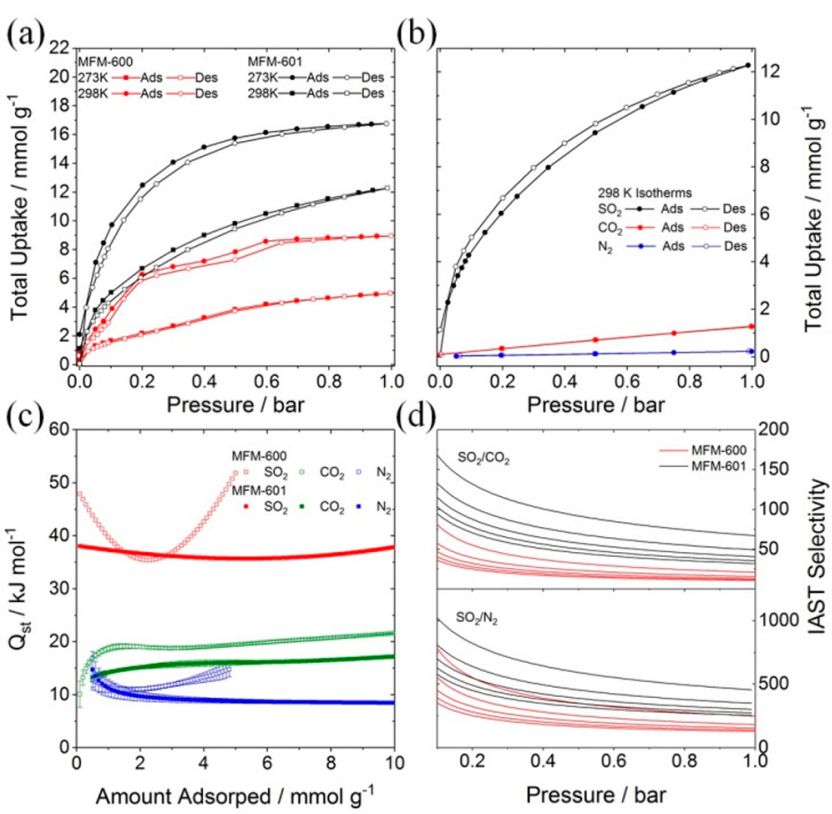

Figure 2. (a) $\mathrm{SO}_{2}$ sorption isotherms in MFM-600 and MFM-601. (b) Comparison of $\mathrm{SO}_{2}, \mathrm{CO}_{2}$ and $\mathrm{N}_{2}$ isotherms at $298 \mathrm{~K}$ in MFM601. (c) $Q_{\text {st }}$ values for $\mathrm{SO}_{2}, \mathrm{CO}_{2}$ and $\mathrm{N}_{2}$ in MFM-600 and MFM-601. (d) IAST selectivities of $\mathrm{SO}_{2} / \mathrm{CO}_{2}$ and $\mathrm{SO}_{2} / \mathrm{N}_{2}$ at $298 \mathrm{~K}$ in MFM-600 and MFM-601 as a function of substrate ratios.

601 exhibits a type $\mathrm{V}$ isotherm with slow initial uptake at low pressures before the uptake increases more rapidly at intermediate pressures reaching a plateau at $\sim 24 \mathrm{mmol} \mathrm{g}^{-1}$ at $30 \mathrm{bar}$ and $298 \mathrm{~K}$ (Figure S15). Adsorption of $\mathrm{N}_{2}$ in MFM601 follows a type-I isotherm with a total uptake of $\sim 12 \mathrm{mmol}$ $\mathrm{g}^{-1}$ at 80 bar $298 \mathrm{~K}$. Strikingly, despite the high uptake of $\mathrm{SO}_{2}$ at $298 \mathrm{~K}$ and $1.0 \mathrm{bar}$, under the same conditions the $\mathrm{CO}_{2}$ uptake in MFM-601 compares poorly to other MOFs in the literature, ${ }^{19}$ with a total $\mathrm{CO}_{2}$ uptake of only $1.3 \mathrm{mmol} \mathrm{g}^{-1}$ and a negligible $\mathrm{N}_{2}$ uptake. The isosteric heat of adsorption $\left(Q_{t}\right)$ for $\mathrm{SO}_{2}, \mathrm{CO}_{2}$ and $\mathrm{N}_{2}$ in MFM-600 and MFM-601 are compared in Figure 2c. The same trend is followed for both MOFs with $\mathrm{N}_{2}$ having the lowest $Q_{s t}$ followed by $\mathrm{CO}_{2}$ and then $\mathrm{SO}_{2}$ with the highest $Q_{\mathrm{st}}$. Interestingly the $Q_{\mathrm{st}}$ values for $\mathrm{SO}_{2}$ in MFM-600 are generally higher than in MFM-601, consistent with the smaller cages of MFM-600 affording greater overlap potentials between $\mathrm{SO}_{2}$ molecules and the pore interior. In MFM-600 at low loadings $\mathrm{SO}_{2}$ interacts with binding sites at the MOF surface. As these sites become less available $Q_{\mathrm{st}}$ reduces, but once $\mathrm{SO}_{2}$ fills the pore, $\mathrm{SO}_{2}-\mathrm{SO}_{2}$ dipole interactions lead to an increase in $Q_{t}$.

Analysis of adsorption selectivities at $298 \mathrm{~K}$ using ideal adsorbed solution theory (IAST) shows that the transformation of MFM- 600 to MFM-601 is accompanied by an increase in selectivity of $\mathrm{SO}_{2}$ over both $\mathrm{CO}_{2}$ and $\mathrm{N}_{2}$ (Figure $2)$. The selectivity for equimolar mixtures of $\mathrm{SO}_{2} / \mathrm{CO}_{2}$ and $\mathrm{SO}_{2} / \mathrm{N}_{2}$ in MFM-601 at $298 \mathrm{~K}$ are 32 and 255, respectively, comparable with the leading MOFs in the literature. ${ }^{20}$ The capability of selective separation of $\mathrm{SO}_{2}$ from gas mixtures using fixed-bed packed with MFM-601 has been confirmed by dynamic breakthrough experiments (Figure 3 and SI).

In order to examine the origins of the preferential adsorption of $\mathrm{SO}_{2}$ over $\mathrm{CO}_{2}$ in MFM-601, in situ synchrotron X-ray powder diffraction studies were carried out (Figures 4 and 5). Rietveld refinement of PXRD data for $\mathrm{CO}_{2}$-loaded MFM-601 

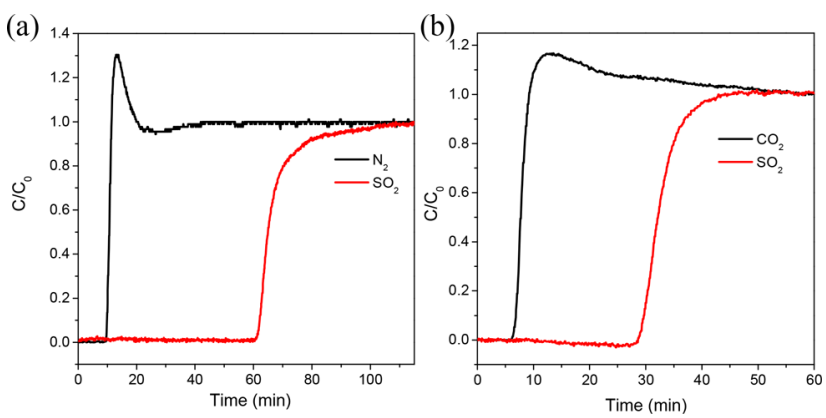

Figure 3. Breakthrough curves of $2500 \mathrm{ppm}$ of $\mathrm{SO}_{2}$ diluted in (a) 1:1 $\mathrm{He}: \mathrm{N}_{2}$ and (b) 1:1 He: $\mathrm{CO}_{2}$ through a fixed-bed packed with MFM601 at $298 \mathrm{~K}$ and 1 bar.

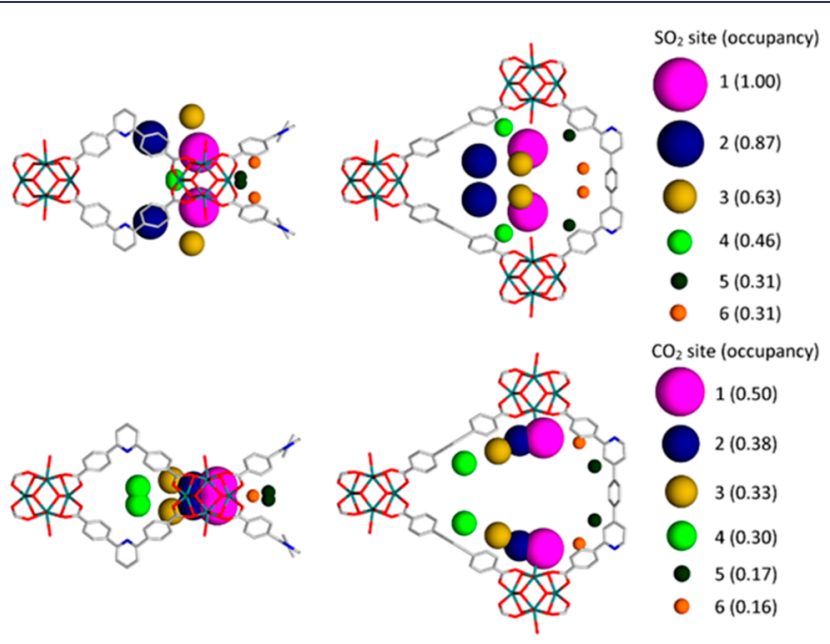

Figure 4. View of $\mathrm{SO}_{2}$ (top) and $\mathrm{CO}_{2}$ (bottom) in MFM-601; the size of the colored balls represent the occupancy at each site. Positions refined by in situ synchrotron PXRD.

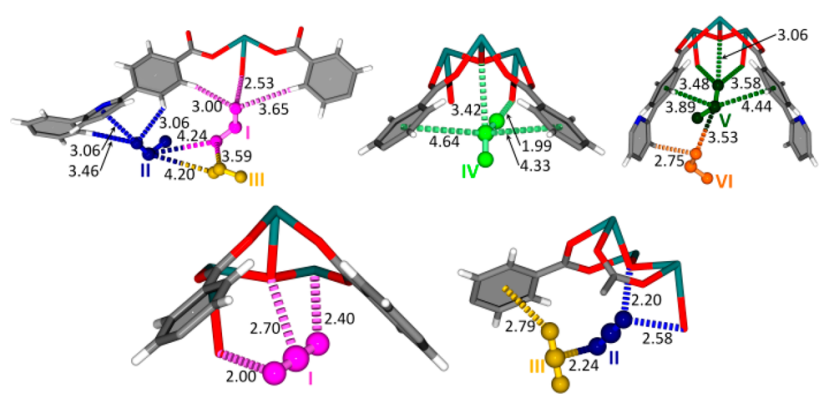

Figure 5. Binding sites of $\mathrm{SO}_{2}$ (top) and $\mathrm{CO}_{2}$ (bottom) in MFM-601.

at $200 \mathrm{~K}$ revealed six binding sites within the pores, giving a formula of $\left[\mathrm{Zr}_{6}\left(\mu_{3}-\mathrm{O}\right)_{4}\left(\mu_{3}-\mathrm{OH}\right)_{4}(\mathrm{OH})_{4}(\mathrm{~L})_{2}\right]\left[\mathrm{CO}_{2}\right]_{5.52}$. The primary binding site of $\mathrm{CO}_{2}{ }^{\mathrm{I}}$ in MFM-601 (occupancy = 0.50) overlaps with the terminal oxygen of the zirconium cluster due to the removal of four $\mathrm{H}_{2} \mathrm{O}$ molecules from each $\left\{\mathrm{Zr}_{6}\right\}$ cluster upon activation, leaving a terminal hydroxyl and an open zirconium site on each of the four equatorial edges of the $\left[\mathrm{Zr}_{6}\left(\mu_{3}-\mathrm{O}\right)_{4}\left(\mu_{3}-\mathrm{OH}\right)_{4}(\mathrm{OH})_{4}\right]^{8+}$ cluster, thus accounting for the 0.5 occupancy of the terminal oxygen and $\mathrm{CO}_{2}{ }_{2}^{\mathrm{I}}$. This positioning of $\mathrm{CO}_{2}{ }^{\mathrm{I}}$ puts it within close proximity to the open zirconium site $\left[\mathrm{O}_{\mathrm{CO} 2} \cdots \mathrm{Zr}=2.40(10) \AA\right]$ as well as being within binding distance of the terminal hydroxyl $\left[\mathrm{C}_{\mathrm{CO} 2} \cdots \mathrm{O}=2.00(24)\right.$ $\AA]$ and the $\mu_{3}-\mathrm{O}$ of the $\mathrm{Zr}_{6} \mathrm{O}_{8}$ cluster $\left[\mathrm{C}_{\mathrm{CO} 2} \cdots \mu_{3}-\mathrm{O}=2.70(11)\right.$ $\AA]$, similar to that observed in $\mathrm{UiO}-66 .{ }^{21} \mathrm{CO}_{2}{ }^{\mathrm{II}}$ (occupancy =
0.38 ) and $\mathrm{CO}_{2}^{\mathrm{VI}}$ (occupancy $=0.16$ ) occupy similar environments either side of the zirconium cluster in that they are both in close proximity to the terminal hydroxyl $\left[\left(\mathrm{O}_{\mathrm{CO} 2} \cdots \mathrm{O}=\right.\right.$ $2.58(23) \AA)$ and $\left[\mathrm{O}_{\mathrm{CO} 2} \cdots \mathrm{O}=3.31(44) \AA\right]$, respectively, as well

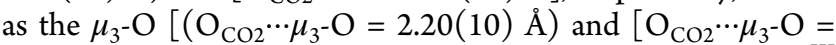
$3.37(14) \AA]$, respectively. The remaining sites, $\mathrm{CO}_{2}{ }^{\mathrm{III}}$ (occupancy $=0.33), \mathrm{CO}_{2}{ }^{\mathrm{IV}}$ (occupancy $\left.=0.30\right)$ and $\mathrm{CO}_{2}{ }^{\mathrm{V}}$ (occupancy $=0.17$ ), are not within binding distance of the $\left\{\mathrm{Zr}_{6}\right\}$ cluster but are closer to the $\mathrm{L}^{4-}$ linker. $\mathrm{CO}_{2}{ }^{\mathrm{III}}$ is near the phenyl ring of the linker $\left[\mathrm{O}_{\mathrm{CO} 2} \cdots \mathrm{Ph}=2.79(8) \AA\right]$ whereas $\mathrm{CO}_{2}{ }^{\mathrm{IV}}$ and $\mathrm{CO}_{2}{ }^{\mathrm{V}}$ are close to the pyridyl rings $\left[\mathrm{O}_{\mathrm{CO} 2} \cdots \mathrm{N}_{\mathrm{Pyr}}=\right.$ $4.38(5) \AA)]$ and $\left[\mathrm{O}_{\mathrm{CO} 2} \cdots \mathrm{H}_{\mathrm{Pyr}}=3.91(25) \AA\right]$, respectively. All $\mathrm{CO}_{2}$ sites are within intermolecular binding distance of one another with $\mathrm{C} \cdots \mathrm{O}$ distances between 2.18 (14) and 4.38(12) $\AA$. However, no ordered $\mathrm{CO}_{2}$ molecule was present at the center of the large pore of MFM-601, thus confirming that $\mathrm{CO}_{2}$ positioning is dominated by host-guest interactions.

The crystal structure of $\mathrm{SO}_{2}$-loaded MFM-601 at $298 \mathrm{~K}$ also shows six binding sites within the pore giving a formula of $\left[\mathrm{Zr}_{6}\left(\mu_{3}-\mathrm{O}\right)_{4}\left(\mu_{3}-\mathrm{OH}\right)_{4}(\mathrm{OH})_{4}\left(\mathrm{H}_{2} \mathrm{O}\right)_{4}(\mathrm{~L})_{2}\right]\left[\mathrm{SO}_{2}\right]_{10.71}$. The three $\mathrm{SO}_{2}$ positions with the highest occupancies, $\mathrm{SO}_{2}{ }^{\mathrm{I}}$ (occupancy $=$ $1.00), \mathrm{SO}_{2}{ }^{\mathrm{II}}$ (occupancy $\left.=0.87\right)$ and $\mathrm{SO}_{2}{ }^{\mathrm{III}}($ occupancy $=0.63)$ form an intermolecular dipole bonding network with $\mathrm{S} \cdots \mathrm{O}$ bond distances between 3.59(7) and 3.24(6) Å, thus exhibiting efficient packing as exhibited by the similarity to the intermolecular distances observed in solid $\mathrm{SO}_{2}{ }^{22}$ The highest occupied $\mathrm{SO}_{2}$ position $\left(\mathrm{SO}_{2}{ }^{\mathrm{I}}\right)$ is located near the terminal hydroxyl of the $\left\{\mathrm{Zr}_{6}\right\}$ cluster $\left[\mathrm{O}_{\mathrm{SO}_{2}} \cdots \mathrm{O}=2.53(6) \AA\right]$ with a similar $\mathrm{SO}_{2}$-hydroxyl interaction to that observed in MFM300 (In). ${ }^{20 \mathrm{~b}} \mathrm{SO}_{2}{ }^{\mathrm{II}}$ sits away from the zirconium cluster, close to the pyridyl group of the $\mathrm{L}^{4-}$ linker $\left[\mathrm{O}_{\mathrm{SO} 2} \cdots \mathrm{Pyr}=3.06(6) \AA\right]$.

Conversely, $\mathrm{SO}_{2}{ }^{\mathrm{III}}$ is not in close proximity to the pore wall and is only within interaction distance of other $\mathrm{SO}_{2}$ molecules. $\mathrm{SO}_{2}{ }^{\mathrm{IV}}$ (occupancy $=0.46$ ) occupies a position between two phenyl rings of two opposite linkers related by a mirror plane. It is in close proximity to both the terminal hydroxyl $\left[\mathrm{O}_{\mathrm{SO} 2} \cdots \mathrm{O}\right.$ $=1.99(10) \AA]$ and the $\mu_{3}-\mathrm{O}\left[\mathrm{S}_{\mathrm{SO}_{2}} \cdots \mu_{3}-\mathrm{O}=3.42(5) \AA\right]$ of the $\left[\mathrm{Zr}_{6}\left(\mu_{3}-\mathrm{O}\right)_{4}\left(\mu_{3}-\mathrm{OH}\right)_{4}(\mathrm{OH})_{4}\left(\mathrm{H}_{2} \mathrm{O}\right)_{4}\right]^{8+}$ cluster. As for $\mathrm{SO}_{2}{ }^{\mathrm{IV}}$, $\mathrm{SO}_{2}{ }^{\mathrm{V}}$ (occupancy $=0.31$ ) resides in between the phenyl rings of two opposite $\mathrm{L}^{4-}$ linkers and also is in close proximity to the terminal hydroxyl $\left[\mathrm{O}_{\mathrm{SO}_{2}} \cdots \mathrm{O}=3.48(15) \AA\right]$ and the $\mu_{3}-\mathrm{O}$ $\left[\mathrm{O}_{\mathrm{SO} 2} \cdots \mu_{3}-\mathrm{O}=3.06(15) \AA\right]$ of the $\left\{\mathrm{Zr}_{6}\right\}$ cluster. The least occupied $\mathrm{SO}_{2}$ site $\left(\mathrm{SO}_{2}{ }^{\mathrm{VI}}\right.$; occupancy $\left.=0.31\right)$ lies near to a pyridyl ring of the organic linker $\left[\mathrm{O}_{\mathrm{SO} 2} \cdots \mathrm{H}_{\mathrm{Pyr}}=2.75(19) \AA\right]$ and also exhibits the potential for dipole-dipole interaction with $\mathrm{SO}_{2}{ }^{\mathrm{V}}\left[\mathrm{O}^{\mathrm{VI}} \ldots \mathrm{S}^{\mathrm{V}}=3.53(18) \AA\right]$ (Figures 4 and 5).

In conclusion, exceptional adsorption of $\mathrm{SO}_{2}$ and selective sorption of $\mathrm{SO}_{2}$ over $\mathrm{CO}_{2}$ and $\mathrm{N}_{2}$ have been demonstrated in a robust Zr-based MOF, MFM-601. By locating the positions of $\mathrm{CO}_{2}$ and $\mathrm{SO}_{2}$ in MFM-601, key understanding of the observed uptake and selectivity has been gained. It has been shown that the dipole moment of $\mathrm{SO}_{2}$ can be utilized by MFM- 601 not only to provide stable binding within the pores but also to drive intermolecular interactions between $\mathrm{SO}_{2}$ molecules.

\section{ASSOCIATED CONTENT}

\section{Supporting Information}

The Supporting Information is available free of charge on the ACS Publications website at DOI: $10.1021 /$ jacs.8b08433.

Data for $\left(\mathrm{C}_{475.2} \mathrm{H}_{248} \mathrm{~N}_{21.6} \mathrm{O}_{139.2} \mathrm{Zr}_{24}\right)$ (CIF)

Data for $\mathrm{C}_{44} \mathrm{H}_{24} \mathrm{~N}_{2} \mathrm{O}_{16} \mathrm{Zr}_{3}$ (CIF)

Data for $\mathrm{C}_{44} \mathrm{H}_{24} \mathrm{~N}_{2} \mathrm{O}_{14} \mathrm{Zr}_{3}, 7.36\left(\mathrm{CO}_{2}\right)$ (CIF) 
Data for $\mathrm{C}_{44} \mathrm{H}_{24} \mathrm{~N}_{2} \mathrm{O}_{16} \mathrm{Zr}_{3}, 14.272\left(\mathrm{SO}_{2}\right)$ (CIF)

Synthesis, characterization, and analysis of crystal structures (PDF)

\section{AUTHOR INFORMATION}

\section{Corresponding Authors}

*Sihai.Yang@manchester.ac.uk;

*M.Schroder@manchester.ac.uk

\section{ORCID}

Sihai Yang: 0000-0002-1111-9272

Martin Schröder: 0000-0001-6992-0700

\section{Notes}

The authors declare no competing financial interest.

CCDC-1850112, 1854228, 1854229 and 1854234 contain the supplementary crystallographic data.

\section{ACKNOWLEDGMENTS}

We thank EPSRC (EP/I011870), ERC (AdG 742041) and University of Manchester for funding. We thank Diamond Light Source for access to Beamline I11 and for awarding J.H.C. a Ph.D. scholarship.

\section{REFERENCES}

(1) U.S. Energy Information Administration. International Energy Outlook 2017; U.S. Energy Information Administration: Washington, DC, 2017.

(2) Gary, J. H.; Handwerk, G. E. Petroleum Refining Technology and Economics, 4th ed.; Marcel Dekker: New York, 2001.

(3) (a) Committee on Acute Exposure Guideline Levels, Committee on Toxicology, Board on Environmental Studies and Toxicology. Acute Exposure Guideline Levels for Selected Airborne Chemicals; National Academies Press: Washington DC, 2010; Vol. 8. (b) World Health Organisation report. WHO Air Quality Guidelines for Particulate Matter, Ozone, Nitrogen Dioxide and Sulfur Dioxide, 2005. (c) Huang, H. Int. J. Environ. Stud. 1992, 41, 267-275.

(4) Lee, J.-Y.; Keener, T. C.; Yang, Y. J. J. Air Waste Manage. Assoc. 2009, 59, 725-732.

(5) (a) Deng, H.; Yi, H.; Tang, X.; Yu, Q.; Ning, P.; Yang, L. Chem. Eng. J. 2012, 188, 77-85. (b) Matito-Martos, I.; Martin-Calvo, A.; Gutiérrez-Sevillano, J. J.; Haranczyk, M.; Doblare, M.; Parra, J. B.; Ania, C. O.; Calero, S. Phys. Chem. Chem. Phys. 2014, 16, 1988419893.

(6) Zhang, Z.; Wu, L.; Dong, J.; Li, B.-G.; Zhu, S. Ind. Eng. Chem. Res. 2009, 48, 2142-2148.

(7) Xia, L.; Cui, Q.; Suo, X.; Li, Y.; Cui, X.; Yang, Q.; Xu, J.; Yang, Y.; Xing, H. Adv. Funct. Mater. 2018, 28, 1704292.

(8) Yi, H.; Wang, Z.; Liu, H.; Tang, X.; Ma, D.; Zhao, S.; Zhang, B.; Gao, F.; Zuo, Y. J. Chem. Eng. Data 2014, 59, 1556-1563.

(9) Yaghi, O. M.; O’Keeffe, M.; Ockwig, N. W.; Chae, H. K.; Eddaoudi, M.; Kim, J. Nature 2003, 423, 705-714.

(10) Zhou, H.-C.; Long, J. R.; Yaghi, O. M. Chem. Rev. 2012, 112, 673-674.

(11) (a) Li, J.-R.; Sculley, J.; Zhou, H.-C. Chem. Rev. 2012, 112, 869-932. (b) Li, H.; Wang, K.; Sun, Y.; Lollar, C. T.; Li, J.; Zhou, H.C. Mater. Today 2018, 21, 108-121. (c) Lin, R.-B.; Xiang, S.; Xing, H.; Zhou, W.; Chen, B. Coord. Chem. Rev. 2017, DOI: 10.1016/ j.ccr.2017.09.027.

(12) Cavka, J. H.; Jakobsen, S.; Olsbye, U.; Guillou, N.; Lamberti, C.; Bordiga, S.; Lillerud, K. P. J. Am. Chem. Soc. 2008, 130, 1385013851.

(13) Planas, N.; Mondloch, J. E.; Tussupbayev, S.; Borycz, J.; Gagliardi, L.; Hupp, J. T.; Farha, O. K.; Cramer, C. J. J. Phys. Chem. Lett. 2014, 5, 3716-3723.

(14) Wang, B.; Yang, Q.; Guo, C.; Sun, Y.; Xie, L.-H.; Li, J.-R. ACS Appl. Mater. Interfaces 2017, 9, 10286-10295.
(15) Wang, T. C.; Vermeulen, N. A.; Kim, I. S.; Martinson, A. B. F.; Stoddart, J. F.; Hupp, J. T.; Farha, O. K. Nat. Protoc. 2016, 11, 149162.

(16) Piscopo, C. G.; Polyzoidis, A.; Schwarzer, M.; Loebbecke, S. Microporous Mesoporous Mater. 2015, 208, 30-35.

(17) Yang, S.; Liu, L.; Sun, J.; Thomas, K. M.; Davies, A. J.; George, M. W.; Blake, A. J.; Hill, A. H.; Fitch, A. N.; Tang, C. C.; Schröder, M. J. Am. Chem. Soc. 2013, 135, 4954-4957.

(18) Tan, K.; Canepa, P.; Gong, Q.; Liu, J.; Johnson, D. H.; Dyevoich, A.; Thallapally, P. K.; Thonhauser, T.; Li, J.; Chabal, Y. Chem. Mater. 2013, 25, 4653-4662.

(19) Trickett, C. A.; Helal, A.; Al-Maythalony, B. A.; Yamani, Z. H.; Cordova, K. E.; Yaghi, O. M. Nat. Rev. Mater. 2017, 2, 17045.

(20) (a) Cui, X.; Yang, Q.; Yang, L.; Krishna, R.; Zhang, Z.; Bao, Z.; Wu, H.; Ren, Q.; Zhou, W.; Chen, B.; Xing, H. Adv. Mater. 2017, 29, 1606929. (b) Savage, M.; Cheng, Y.; Easun, T. L.; Eyley, J. E.; Argent, S. P.; Warren, M. R.; Lewis, W.; Murray, C.; Tang, C. C.; Frogley, M. D.; Cinque, G.; Sun, J.; Rudić, S.; Murden, R. T.; Benham, M. J.; Fitch, A. N.; Blake, A. J.; Ramirez-Cuesta, A. J.; Yang, S.; Schröder, M. Adv. Mater. 2016, 28, 8705-8711.

(21) (a) Wu, H.; Shen Chua, Y. S.; Krungleviciute, V.; Tyagi, M.; Chen, P.; Yildirim, T.; Zhou, W. J. Am. Chem. Soc. 2013, 135, 1052510532. (b) Chevreau, H.; Liang, W.; Kearley, G. J.; Duyker, S. G.; D’Alessandro, D. M.; Peterson, V. K. J. Phys. Chem. C 2015, 119, 6980-6987.

(22) Post, B.; Schwartz, R. S.; Fankuchen, I. Acta Crystallogr. 1952, $5,372-374$. 